\title{
Helseforskningsloven
}

Lov om medisinsk og helsefaglig forskning, helseforskningsloven (1), trer i kraft 1. juli 2009. Med det er en mer enn seks år lang prosess over, og Norge har fått et nytt, omfattende lovgrunnlag for godkjenning, gjennomføring, offentliggjøring og tilsyn med medisinsk forskning. Regjeringen Bondevik II oppnevnte våren 2003 et utvalg (Nylenna-utvalget) som skulle utrede reguleringen av medisinsk forskning og komme med forslag til eventuelle endringer. Utvalget avdekket et omfattende, men fragmentert og uoversiktlig regelverk (2). Regelverket ble dessuten håndhevet av et titall kontroll- og tilsynsorganer med til dels overlappende oppgaver. På denne bakgrunn foreslo utvalget en ny, helhetlig lov for medisinsk og helsefaglig forskning og en betydelig samordning av kontroll- og tilsynssystemet (3). Etter en omfattende høring fremla regjeringen Stoltenberg II sommeren 2007 et lovforslag for Stortinget (4). Etter noe politisk dragkamp ble loven med mindre endringer vedtatt 27. mai 2008. Med tillegg av en forskrift, som gir nærmere regler for organisering og forhåndsgodkjenning, blir loven nå gjeldende.

I $§ 1$ heter det at «lovens formål er å fremme god og etisk forsvarlig medisinsk og helsefaglig forskning». Dermed understrekes det at medisinsk og helsefaglig forskning er en grunnleggende og ønsket samfunnsnyttig aktivitet. All «virksomhet som utføres med vitenskapelig metodikk for å skaffe til veie ny kunnskap om helse og sykdom» (§ $4 \mathrm{a})$ omfattes av loven, uavhengig av hvilke faggrupper som utfører forskningen. I forarbeidene fastslås det eksplisitt at studentprosjekter faller inn under loven. Grensen mot kvalitetssikringsprosjekter og utprøvende behandling vil, som tidligere, kunne være vanskelig å trekke i praksis. Ved tvil skal spørsmålet forelegges regional etikkomité.

Forsvarlighet i organisering og gjennomføring av forskning er grunnkravet i helseforskningsloven $(\S 5)$. I det ligger at forskningen skal «ivareta etiske, medisinske, helsefaglige, vitenskapelige og personvernmessige forhold» $(\S 5,3$. avsnitt). Forskningsdeltakere skal ikke utsettes for unødvendig eller uforholdsmessig risiko og ulemper. Helsinki-deklarasjonens hovedprinsipp om at «hensynet til deltakernes velferd og integritet skal gå foran vitenskapen og samfunnets interesser» lovfestes ( $§ 5,2$. avsnitt). Videre skal all forskning organiseres som prosjekt med forskningsansvarlig, prosjektleder og forskningsprotokoll ( $(6)$. «Forskningsansvarlig» er et nytt begrep. Forskningsansvarlig vil normalt være en institusjon - et universitet, et helseforetak, et farmasøytisk firma e.l. - med overordnet systemansvar for forskningsprosjektet. Det inkluderer infrastruktur, pasient- og informasjonssikkerhetsmessige forhold og internkontroll. Behovet for et slikt overordnet ansvar har blant annet vist seg ved mistenkt eller påvist uredelighet i forskning. Ved multisenterstudier vil alle deltakende virksomheter måtte ha en forskningsansvarlig. Slik deles det overordnede ansvar for prosjektet. Det skal imidlertid alltid være kun én prosjektleder, som skal være en person med tilstrekkelig helsefaglig og vitenskapelig kompetanse. Prosjektleder skal sørge for forhåndsgodkjenning, kommunikasjon med offentlige instanser og den daglige drift av prosjektet. Forskriften fastsetter relativt detaljerte regler for innholdet i forskningsprotokollen.

Kravet til frivillig og informert samtykke er et hevdvunnet prinsipp i medisinsk forskning. Den nye loven stadfester dette og slår endatil fast at unntak må hjemles i lov. Til gjengjeld fastsettes det regler for forskning på barn og personer uten samtykkekompetanse, noe som hittil har vært uklart og mangelfullt regulert. Også vilkårene for forskning i kliniske nødssituasjoner, for eksempel ved ulykker, klargjøres. Mens det tidligere har vært nødvendig å innhente nytt samtykke selv ved mindre endringer i et forskningsprosjekt, innfører loven muligheten for å innhente såkalt bredt samtykke. Et slikt «bredt samtykke» kan omfatte ett eller flere overordnede forskningsformål og -felter, som for eksempel hjerteforskning eller kreftforskning. Dessuten kan det, dersom forskningen er av vesentlig interesse for samfunnet og hensynet til deltakerens velferd og integritet er ivaretatt, gis adgang til bruk av helseopplysninger som er innsamlet i ordinært diagnostisk og terapeutisk arbeid i helsetjenesten $(\S 35)$.

Forhåndsgodkjenningen av forskningsprosjekter blir betydelig forenklet. De regionale komiteer for medisinsk og helsefaglig forskningsetikk (REK) har fått utvidet ansvar og myndighet. Disse komiteene, som ble lovfestet i 2007 (5), blir nå normalt den eneste instans forskere må forholde seg til. De regionale etikkomiteene har blant annet fătt overført myndighet fra Datatilsynet og Helsedirektoratet til å opprette forskningsregistre og forskningsbiobanker. Den nasjonale komité for medisinsk og helsefaglig forskningsetikk er ankeinstans. Unntaket er utprøvning av legemidler, der Statens legemiddelverk også må godkjenne prosjektet. I tillegg skal Helsedirektoratet involveres ved klinisk utprøvning av medisinsk utstyr og ved forskning som faller inn under bioteknologiloven. En regional etikkomité skal forhåndsgodkjenne alle forskningsprosjekter. Komiteen skal vurdere forskningsprosjektets begrunnelse, mål, metodevalg, risiko-nytte-forhold, innhenting av samtykke og informasjonsskriv til deltakerne etc. Komiteen kan fastsette vilkår for godkjenningen. Komiteene skal gi allmennheten innsyn i pågående forskningsprosjekter og innsyn i sluttmeldinger, noe alle prosjektledere må sende inn når prosjektet avsluttes. Åpenhet og innsyn er et naturlig og økende krav til all medisinsk og helsefaglig forskning. Etikkomiteenes lovanvendelse og evne til å leve opp til forventningene blir avgjørende for at helseforskningslovens intensjoner og mål oppfylles.

\section{Magne Nylenna}

magne.nylenna@kunnskapssenteret.no

Sigmund Simonsen

sigmund.simonsen@ntnu.no

Magne Nylenna (f. 1952) er fungerende direktør ved Nasjonalt kunnskapssenter for helsetjenesten og professor II i samfunnsmedisin ved Norges teknisk-naturvitenskapelige universitet og Universitetet i Oslo. Han var leder av Nylenna-utvalget, som utarbeidet utkast til helseforskningsloven.

Sigmund Simonsen (f. 1972) er advokat og stipendiat i helseforskningsrett ved Norges teknisk-naturvitenskapelige universitet. Han var sekretariatsleder for Nylenna-utvalget.

\section{Litteratu}

1. Lov 2008-06-20 nr 44. Lov om medisinsk og helsefaglig forskning (helseforskningsloven).

Simonsen S, Nylenna M. Regulering av medisinsk forskning - hvorfor og hvordan? Tidsskr Nor Lægeforen 2004; 124: 2133-6.

3. Norges offentlige utredninger. God forskning - bedre helse. NOU 2005: 1.

Ot.prp. nr. 74 (2006-2007). Om lov om medisinsk og helsefaglig forskning (helseforskningsloven).

5. Lov 2006-06-30 nr 56. Lov om behandling av etikk og redelighet i forskning 